\title{
Nutrient-hormone interaction in the ovine liver: methionine supply selectively modulates growth hormone-induced IGF-I gene expression
}

\author{
A K Stubbs, N M Wheelhouse, M A Lomax and D G Hazlerigg \\ Animal Biology Group/Aberdeen Centre for Energy Regulation and Obesity (ACERO), Department of Agriculture and Forestry, MacRobert Building, \\ University of Aberdeen, 581 King Street, Aberdeen, AB24 5UA, UK \\ (Requests for offprints should be addressed to D G Hazlerigg; Email: d.hazlerigg@abdn.ac.uk) \\ (N M Wheelhouse is now at Department of Pathology, University of Edinburgh Medical School, Teviot Place, Edinburgh EH8 9AG, UK) \\ (A K Stubbs is now at Wellcome Trust Cellular Physiology Research Unit, Department of Physiology, University College Cork, Ireland) \\ (A K Stubbs and N M Wheelhouse contributed equally to this work)
}

\begin{abstract}
This study tested the hypothesis that specific amino acids are responsible for modulating the insulin-like growth factor-I (IGF-I) response to growth hormone $(\mathrm{GH})$ in ovine hepatocytes. Cells were grown in media of defined amino acid composition, based on physiological concentrations (P.C.) of amino acids in sheep plasma. Relative to culture in $5 \times$ P.C., amino acid limitation to $0.2 \times$ P.C. had inhibitory effects on IGF-I RNA expression, peptide release and p70 S6 kinase phosphorylation $(P<0 \cdot 01$ in each case). Limitation of methionine levels to $0.2 \times$ P.C. against a background of $5 \times$ P.C. for the other amino acids blocked GH-stimulated IGF-I peptide release and RNA expression, although basal expression was unaffected. In contrast, limitation of the other amino acids present in the culture medium had no effect on basal or GH-stimulated IGF-I expression. Selective methionine limitation to $0 \cdot 2 \times$ P.C. levels had no effect on cellular or secretory protein synthesis rates relative to cells grown in complete
\end{abstract}

$5 \times$ P.C. medium but did cause a partial reduction in $\mathrm{p} 70$ S6 kinase phosphorylation, which was also observed when medium was selectively limited for other essential amino acids. The addition of rapamycin $(5 \mathrm{ng} / \mathrm{ml})$ to cells grown in $5 \times$ P.C. media completely abolished p70 S6 kinase phosphorylation $(P<0 \cdot 001)$, implicating $\mathrm{mTOR}$ in the response of S6 kinase phosphorylation to changing amino acid supply. By contrast, inclusion of rapamycin (100 ng/ $\mathrm{ml}$ ) had no effect on levels of IGF-I gene expression. These results indicate that methionine is the key limiting amino acid involved in the modulation of IGF-I expression in the ovine liver. This nutrient-hormone interaction is a highly selective phenomenon, occurring against a background of modest effects on general protein synthetic control. The partial inhibitory effects of methionine on mTOR activity are not sufficient to account for this selectivity of action.

Journal of Endocrinology (2002) 174, 335-341

\section{Introduction}

The endocrine control of growth is driven by the pituitary hormone, somatotrophin/growth hormone (GH). Many of the peripheral actions of $\mathrm{GH}$ are indirect, and mediated by insulin-like growth factor-I (IGF-I) (Gluckman et al. 1987). The GH/IGF-I axis has been proposed as a mediator of the effects of nutrient supply on growth (Breier et al. 1988). IGF-I gene expression has a wide tissue distribution, including the liver and skeletal muscle, but the bulk of circulatory IGF-I is of hepatic origin (Schwander et al. 1983). Studies in transgenic animals indicate that normal growth and development depends on both local (paracrine) and circulatory (endocrine) IGF-I production (Sjögren et al. 1999, Yakar et al. 1999, Silha et al. 2001).
Low protein diets reduce circulating titres of IGF-I (Wyn et al. 1991), and cause a loss of hepatic responsiveness to GH (Kriel et al. 1982, Breier et al. 1988, Ketelslegers et al. 1995). Depressed IGF-I titres caused by protein restriction are associated with reduced levels of IGF-I mRNA in the liver (Van de Haar et al. 1991, Pell et al. 1993), and these effects are mirrored by those of amino acid limitation on cultured hepatocytes, with basal and GH-stimulated IGF-I mRNA levels and peptide production being reduced in vitro (Harp et al. 1991, Thissen et al. 1994, Wheelhouse et al. 1999). Expression of IGF-I RNA or peptide in amino acid-restricted hepatocytes is reduced, and these cells become unresponsive to GH (Harp et al. 1991, Thissen et al. 1994, Wheelhouse et al. 1999). 
It remains unclear how changes in amino acid supply are initially transduced into changes in gene expression, or whether specific amino acids are of greater importance than others in modulating GH-induced IGF-I gene expression. The mammalian orthologue of yeast TOR (for Target of Rapamycin), mTOR, relays signals through the protein kinase B (PKB)/Akt pathway (Campbell et al. 1999), and is highly sensitive to amino acid supply in mammalian cells (Hara et al. 1998, Wang et al. 1998, Iiboshi et al. 1999, Shigemitsu et al. 1999). This pathway modulates translation initiation through effects on the activity of eukaryotic initiation factor-4E (eIF-4E), and ribosomal p70 S6 kinase (Jefferies et al. 1997, Proud \& Denton 1997). Additionally, the phosphorylation of the transcription factors STAT3 and CCAAT/enhancer binding protein $\alpha(\mathrm{C} / \mathrm{EBP} \alpha)$, is mTOR-dependent (Hemati et al. 1997, Yokogami et al. 2000), suggesting that effects on mTOR activity could mediate effects of amino acid supply on mammalian gene expression.

Hence the present study determined the effect of selectively limiting individual amino acids on $\mathrm{GH}-$ induced IGF-I expression in cultured ovine hepatocytes, and assessed the role of $\mathrm{mTOR}$ in this response to amino acid supply.

\section{Materials and Methods}

\section{Preparation of sheep hepatocytes}

Ovine hepatocyes were prepared from sheep killed at a local abattoir as previously described (Wheelhouse et al. 1999). In all cell preparations approximately $90 \%$ of the cells were viable as determined by ability to exclude Trypan blue. Cells were plated in collagen-coated tissue culture plates at $1 \times 10^{6}$ viable cells $/ \mathrm{ml}$ of recovery medium (Eagle's Minimal Essential Medium supplemented with 10\% newborn calf serum, Insulin Transferrin Selenite media supplement (Sigma Chemicals Company, Poole, Dorset, UK), 0.4 nM dexamethasone, 0.15 nM tri-iodothyronine, antibiotic/antimycotic (Gibco BRL, Paisley, Strathclyde, UK), $4 \cdot 2 \mathrm{mM}$ sodium acetate, $0.33 \mathrm{mM}$ sodium butyrate, $2.0 \mathrm{mM}$ sodium propionate and $1.15 \mathrm{mM}$ calcium lactate). The cells were incubated at $37^{\circ} \mathrm{C}$ in $5 \% \mathrm{CO}_{2}$ for four hours before transfer to incubation media.

\section{Incubation media}

Test media were made using constituents of the RPMI1640 Select-Amine kit (Gibco BRL). Hormone and volatile fatty acid (VFA) concentrations were as described for recovery media. Free amino acid concentrations were $5 \times, 1 \times$, and $0 \cdot 2 \times$ physiological concentrations (P.C.) based upon in vivo ovine portal venous blood data in ad libitum fed sheep (Lobley et al. 1995).

\section{IGF-I RIA}

Analyses of IGF-I levels in acid ethanol extracts of lyophilized media samples were performed as described previously (Wheelhouse et al. 1999).

\section{Measurement of phosphorylation of $p 70$ S6 kinase}

The phosphorylation of p70 S6 kinase was determined by Western blotting. Cells were lysed in a preheated $\left(95^{\circ} \mathrm{C}\right)$ buffer composed of $12.5 \mathrm{mM}$ Tris $\mathrm{HCl}(\mathrm{pH} 7 \cdot 5), 1 \%$ SDS, $10 \%$ glycerol, $2 \cdot 5 \%$ dithiothreitol and $0 \cdot 04 \%$ bromophenol blue and stored at $-80{ }^{\circ} \mathrm{C}$ until electrophoresis. Proteins were resolved by SDS-PAGE, with a gel acrylamide content of $10 \%$. Resolved proteins were transferred to polyvinylidene difluoride (PVDF) membranes (Polyscreen). Following transfer, membranes were washed briefly in $20 \mathrm{mM}$ Tris $\mathrm{HCl}, 150 \mathrm{mM} \mathrm{NaCl}(\mathrm{pH} 7 \cdot 5)$ (TBS), containing $0 \cdot 1 \% \mathrm{v} / \mathrm{v}$ Tween 20 (TBST), and then incubated for $1 \mathrm{~h}$ at room temperature in TBST containing 3\% non-fat milk powder. Membranes were incubated overnight at $4{ }^{\circ} \mathrm{C}$ in primary antibody solution containing anti-phospho-(Thr 389)-p70 S6 kinase or anti p70 S6 kinase (New England Biolabs, Hitchin, Hertfordshire, UK) diluted 1:1000 in TBST containing $5 \% \mathrm{w} / \mathrm{v}$ bovine serum albumin. The next day membranes were washed five times in TBST, and incubated in secondary antibody solution containing anti-rabbit IgG-horseradish peroxidase conjugate (Transduction Laboratories) diluted 1:2000 in TBST containing $5 \% \mathrm{w} / \mathrm{v}$ bovine serum albumin for $1 \mathrm{~h}$ at room temperature. After the second antibody incubation, membranes were washed as before, and labelled proteins were visualised using the ECL chemiluminescence detection system (Amersham). The intensity of labelled bands was quantified using a LASER densitometer (Amersham) and Phoretix I-D Advanced image analysis software.

\section{Measurement of IGF-I gene expression}

Measurement of IGF-I gene expression was conducted by RNase protection assay (RPA) as described previously (Wheelhouse et al. 1999).

\section{Cellular protein synthesis rates}

Cellular protein synthesis rates were measured by metabolic labelling over a $30-\mathrm{h}$ period, starting $18 \mathrm{~h}$ after transfer to defined media. These experiments were conducted essentially as described previously (Wheelhouse et al. 1999), except that the tracer was $\left[{ }^{3} \mathrm{H}\right]$ leucine, instead of $\left[{ }^{35} \mathrm{~S}\right]$ methionine.

\section{Replication and statistical analyses}

Data were analysed by factorial ANOVA and comparison of individual sample means was made by Fisher's least 
significant difference test. All analyses were conducted using Minitab version 11 (Minitab Inc. Pennsylvania, PA, USA). Positively skewed data were normalised by $\log _{10}$ transformation prior to analysis.

\section{Results}

Effects of limitation of individual amino acids on GH-induced IGF-I release

In ovine hepatocytes grown in $5 \times$ P.C. levels of amino acids, $\mathrm{GH}(10 \mathrm{nM})$ caused an approximately twofold induction of IGF-I peptide release over a 48 -h incubation period (Fig. 1a). By comparison, cells grown in $0 \cdot 2 \times$ P.C. medium had lower basal levels of IGF-I peptide release $(P<0 \cdot 01)$ and were unresponsive to $\mathrm{GH}$ either at $10 \mathrm{nM}$ (Fig. 1) or at any concentrations between 1 and $100 \mathrm{nM}$ (data not shown). Limitation of individual amino acids to $0.2 \times$ P.C. against a background of $5 \times$ P.C. levels had differential effects on this response to GH. In the case of methionine the $\mathrm{GH}$ response was abolished, although basal IGF-I release was similar to that seen in $5 \times$ P.C. medium (Fig. 1a). In contrast, when levels of leucine, isoleucine, valine, cysteine, histidine, lysine, or tryptophan were individually reduced, GH-stimulated IGF-I release was not inhibited relative to levels in $5 \times$ P.C. medium (Fig. $1 b)$.

Effect of amino acid supply on cellular and secretory protein synthesis rates

Consistent with our earlier work (Wheelhouse et al. 1999), cellular protein synthesis was approximately linear up to $30 \mathrm{~h}$ in culture in $5 \times$ P.C. media (Fig. 2a). General limitation of amino acid supply to $0 \cdot 2 \times$ P.C. caused a pronounced reduction in cellular synthesis rates $(P<0 \cdot 001)$; by contrast selective limitation of methionine to $0 \cdot 2 \times$ P.C. did not inhibit cellular protein synthesis over the 30-h period. A similar picture was seen for secretory protein synthesis, except that a lag was apparent in the leucine incorporation into the secretory fraction, reflecting the post-translational processing of secretory proteins (Fig. 2b).

\section{Effect of methionine limitation on IGF-I RNA expression}

Since GH induction of hepatic IGF-I expression occurs through transcriptional activation, we tested the hypothesis that the effects of methionine limitation on IGF-I peptide release stemmed from a reduction of GH-induced IGF-I RNA expression (Fig. 3). In $5 \times$ P.C. medium, GH $(10 \mathrm{nM})$ induced a twofold activation of IGF-I RNA expression $(P<0 \cdot 01)$, and this response was almost completely abolished by general amino acid depletion to

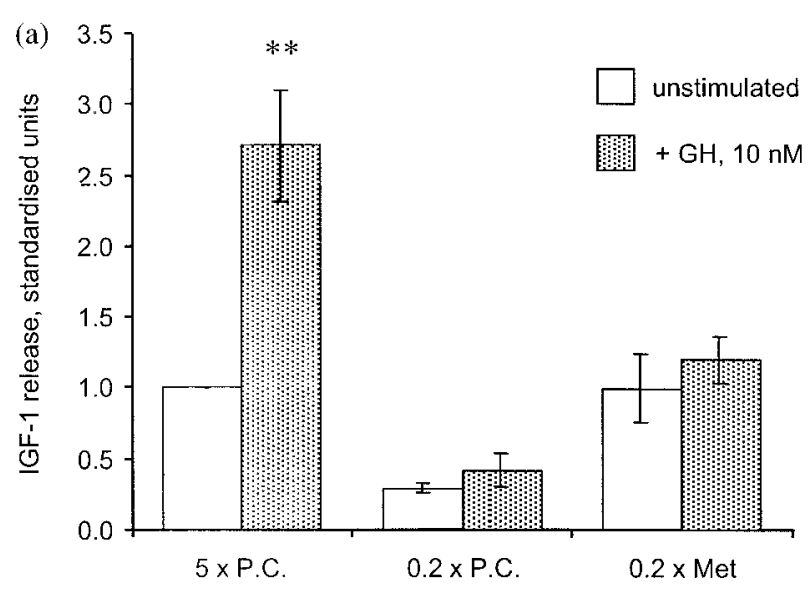

(b)

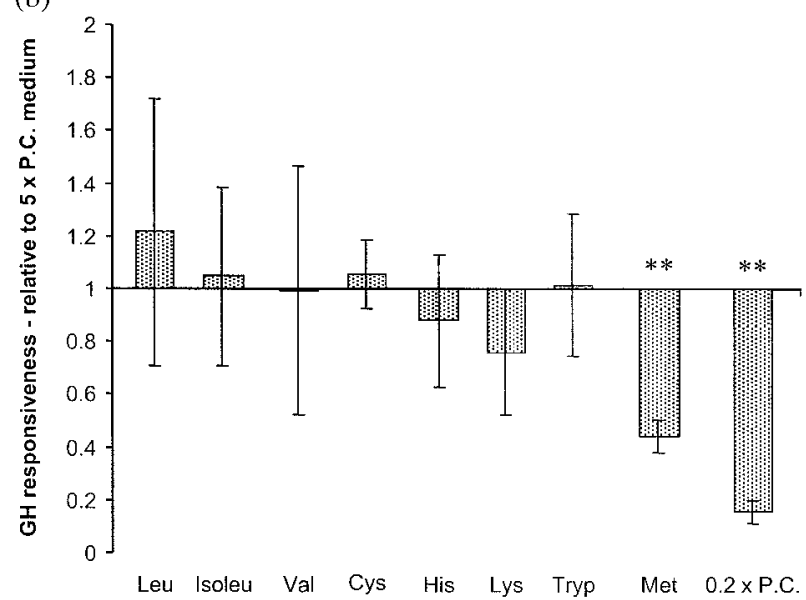

Figure 1 Effect of selective amino acid limitation on IGF-I production. (a) Cells were incubated in complete $5 \times$ physiological concentration (P.C.) or $0.2 \times$ P.C. media, or in $5 \times$ P.C. media selectively depleted of methionine to $0 \cdot 2 \times$ P.C. level $(0 \cdot 2 \times$ Met), and in the absence or presence of $\mathrm{GH}(10 \mathrm{nM})$. Media for the period $24-48 \mathrm{~h}$ in culture were assayed for IGF-I release. Data are normalised against unstimulated IGF-I release in $5 \times$ P.C. medium, and are expressed as means \pm S.E.M. of three separate cultures. ${ }^{*} P<0 \cdot 01$, significantly greater production relative to values in the absence of $\mathrm{GH}$ in the same culture medium. (b) Responsiveness of cells grown in medium selectively limited to $0 \cdot 2 \times$ P.C. for the amino acids indicated (Leu, leucine; Isoleu, isoleucine; Val, valine; Cys, cysteine; His, histidine; Lys, lysine; Tryp, tryptophan; Met, methionine) or for all amino acids. Data are GH-induced IGF-I release expressed as a fraction of the release seen in $\mathrm{GH}$-stimulated cells grown in $5 \times$ P.C. media. ${ }^{*} P<0 \cdot 01$, significantly reduced response to GH. Data are means \pm S.E.M. of three separate cultures.

$0 \cdot 2 \times$ P.C. or by selective limitation of methionine. As was the case for IGF-I peptide release (Fig. 1) general amino acid limitation, but not selective methionine limitation, also reduced basal IGF-I RNA expression. 
(a)

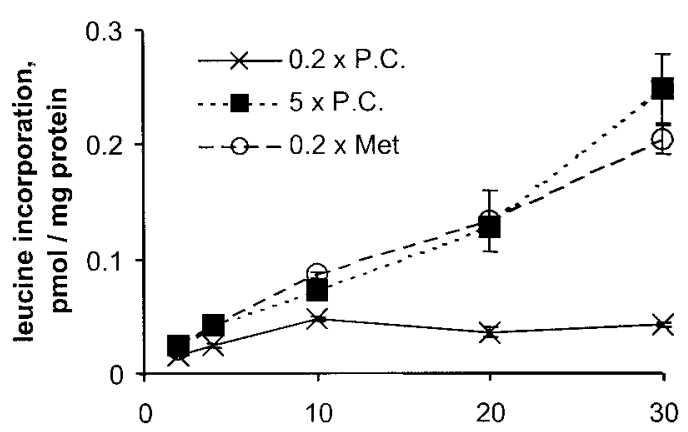

(b)

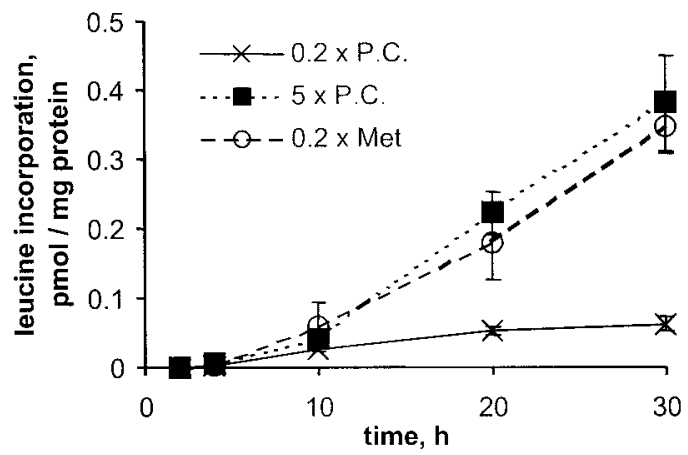

Figure 2 Effect of methionine limitation on cellular and secretory protein synthesis. Cells were grown in $0 \cdot 2 \times$ P.C. or $5 \times$ P.C. medium, or in medium selectively depleted of methionine $(0 \cdot 2 \times$ Met $)$, and labelled with $\left[{ }^{3} \mathrm{H}\right]$ leucine. Leucine incorporation into cellular (a) or secretory (b) protein was determined and normalised against total cellular protein. Data are means \pm S.E.M. from 3 separate experiments.

Effect of general or selective amino acid limitation on p70 S6 kinase phosphorylation in ovine hepatocytes

Immunostaining of Western blots with antisera to phosphorylated (Thr 389) p70 S6 kinase revealed a major band of 70 kiloDaltons $(\mathrm{kDa})$, corresponding to p70 S6 kinase (Fig. 4a). Additionally, the antibody recognised a higher molecular weight species of approximately $85 \mathrm{kDa}$, which probably represents p85 S6 kinase, and a lower weight species of below $57 \mathrm{kDa}$ which was not identified. The intensity of staining of phosphorylated p70 S6 kinase was highly sensitive to amino acid supply, such that exposure to $5 \times$ P.C. media for $2 \mathrm{~h}$ resulted in phosphorylation levels an order of magnitude higher than those exposed to $0.2 \times$ P.C. amino acids for the same period (Fig. 4a,c; $P<0 \cdot 001)$. The stimulatory effect of $5 \times$ P.C. amino acids on p70 S6 kinase phosphorylation was completely blocked by co-addition of the mTOR inhibitor, rapamycin $(5 \mathrm{ng} / \mathrm{ml})$, and at this concentration inhibition was maintained for at least $4 \mathrm{~h}$ (Fig. $4 \mathrm{~b}$ and data not shown). Selective limitation for methionine, or for any of the branched chain amino acids, resulted in

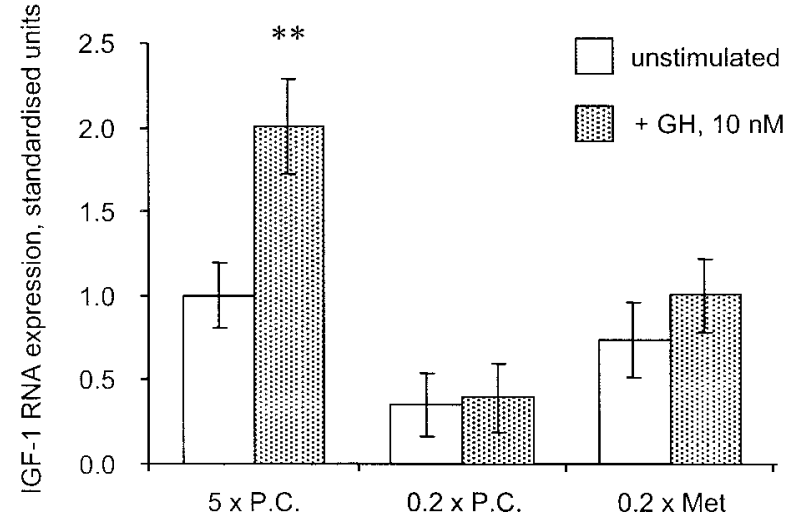

Figure 3 Effect of methionine limitation on IGF-I RNA expression. Cells were incubated in complete $5 \times$ P.C. or $0.2 \times$ P.C. media, or in $5 \times$ P.C. media selectively depleted of methionine $(0 \cdot 2 \times$ Met $)$, and in the absence or presence of $\mathrm{GH}(10 \mathrm{nM})$ as indicated. After $24 \mathrm{~h}, \mathrm{RNA}$ was extracted and IGF-I RNA expression was determined by RNase protection assay. Data are normalised against unstimulated IGF-I expression in $5 \times$ P.C. medium, and are means \pm S.E.M. of three separate cultures. ${ }^{*} P<0 \cdot 01$, significantly greater expression relative to values in the absence of $\mathrm{GH}$ in the same culture medium.

intermediate levels of p70 S6 kinase phosphorylation (Fig. $4 \mathrm{a}, \mathrm{c})$.

\section{Effect of rapamycin on IGF-I expression}

Since both amino acid limitation and rapamycin inhibit phosphorylation of p70 S6 kinase, we tested the possibility that rapamycin would mimic the inhibitory effects of amino acid limitation on IGF-I gene expression. As before, IGF-I RNA expression was highly sensitive to amino acid supply and GH (Fig. 5), with levels in cells grown in $0.2 \times$ P.C. medium being 60-80\% lower than in $5 \times$ P.C. media $(P<0.001$ in both cases). In contrast, rapamycin $(5 \mathrm{ng} / \mathrm{ml})$ completely failed to inhibit basal or GHstimulated IGF-I gene expression. To exclude the possibility that the lack of effect observed in these initial experiments was due to loss of rapamycin bioactivity, we also tested the effects of $100 \mathrm{ng} / \mathrm{ml}$ rapamycin and even under these circumstances no inhibitory effect of rapamycin on IGF-I gene expression was observed (Fig. 5).

\section{Discussion}

The aim of the present study was to investigate the mechanisms through which changes in amino acid supply affect basal and GH-stimulated IGF-I expression in ovine hepatocytes. In previous studies we have shown that general limitation of amino acids to $0 \cdot 2 \times$ P.C. reduces basal IGF-I expression and blocks the stimulatory effect of $\mathrm{GH}$ thereon (Wheelhouse et al. 1999). Here, we used 

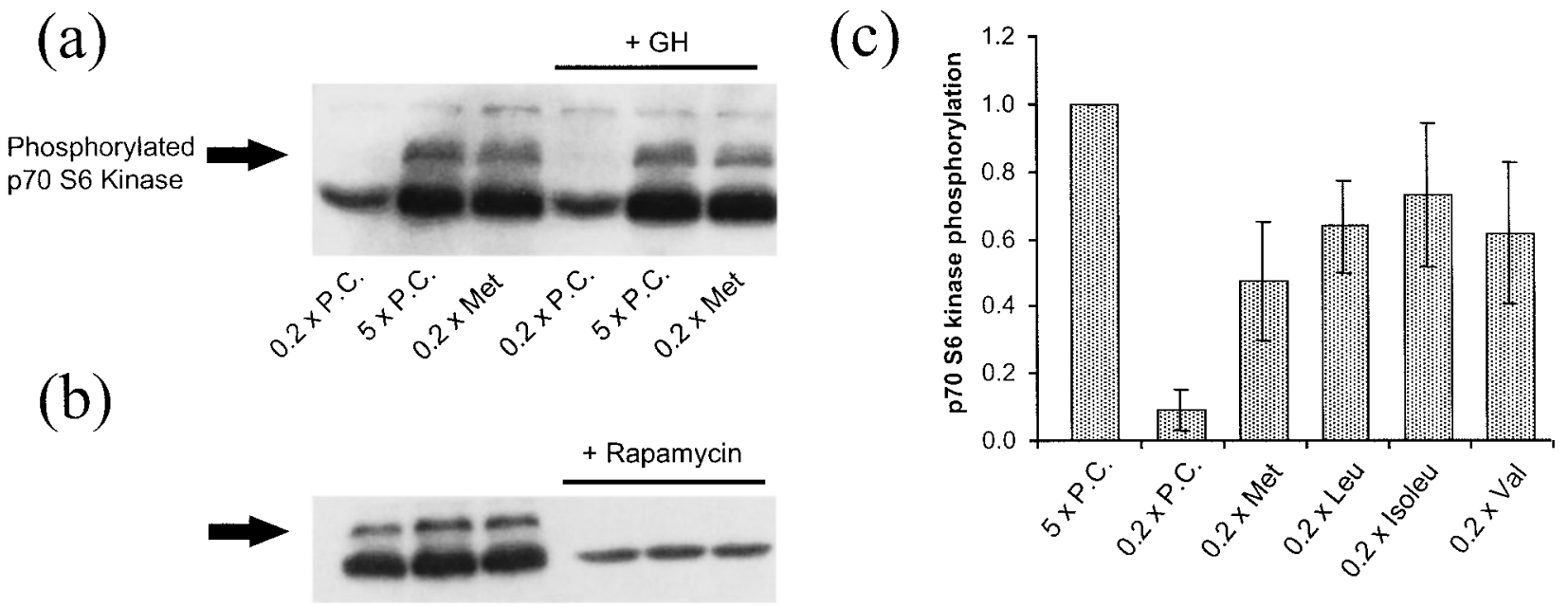

Figure 4 The effect of amino acid availability and rapamycin on p70 S6 kinase phosphorylation. (a) Cells were incubated in $0 \cdot 2 \times$ P.C. or $5 \times$ P.C. media, or in media selectively limited for methionine $(0 \cdot 2 \times$ Met), and in the absence or presence of GH (10 nM), as indicated, for a period of $2 \mathrm{~h}$. Extracts were resolved by SDS-PAGE, blotted and probed with antiserum to phosphorylated p70 S6 kinase. The arrow indicates the band corresponding to phospho-p70 S6 kinase. (b) Cells were incubated in $5 \times$ P.C. media and in the absence or presence of rapamycin $(5 \mathrm{ng} / \mathrm{ml})$ for $2 \mathrm{~h}$ prior to determination of p70 S6 kinase phosphorylation. (c) Relative optical density measurements of p70 S6 kinase phosphorylation under the conditions described in (a), and in cells selectively limited for the branched chain amino acids: leucine $(0 \cdot 2 \times$ Leu $)$, isoleucine $(0 \cdot 2 \times$ Isoleu $)$ or valine $(0 \cdot 2 \times \mathrm{Val})$. Data are means \pm S.E.M. of 3 experiments, expressed relative to phosphorylation levels in cells grown in $5 \times$ P.C. medium.

selective limitation of individual amino acids to $0 \cdot 2 \times$ P.C., against a background of $5 \times$ P.C. levels, to determine whether specific amino acids exert more potent effects than others. Using this approach we found that of those amino acids tested, methionine limitation was uniquely able to block GH-stimulated IGF-I peptide

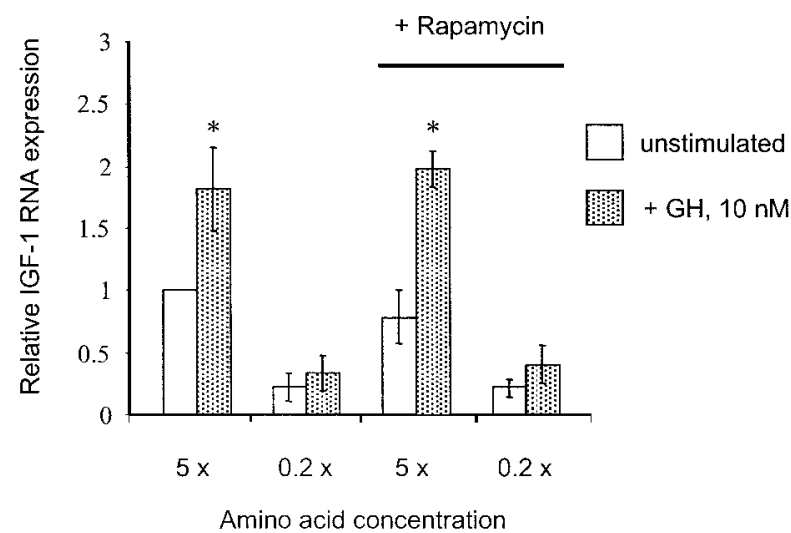

Figure 5 The effect of rapamycin on IGF-I mRNA expression. Cells were grown in $0.2 \times$ P.C. or $5 \times$ P.C. amino acids for a total of $24 \mathrm{~h}$, in the absence or presence of rapamycin $(100 \mathrm{ng} / \mathrm{ml})$ and $\mathrm{GH}(10 \mathrm{nM})$ as indicated, and IGF-I RNA abundance was determined by RNase protection assay. Data are normalised relative to values in $5 \times$ P.C. media with no additions, and are means \pm S.E.M. for 3 experiments. ${ }^{*} P<0 \cdot 05$, significantly greater expression relative to values in the absence of $\mathrm{GH}$ in the same culture medium. release, although unlike general amino acid limitation, no effect was seen on basal IGF-I peptide release.

This effect of methionine was not due to effects on overall cellular or secretory protein synthesis rates although general amino acid limitation clearly affected these parameters. This led us to explore the possibility that a selective effect on IGF-I RNA expression might be involved. Our results are consistent with this hypothesis: methionine limitation selectively ablated the IGF-I RNA response to GH stimulation whilst leaving basal IGF-I RNA levels similar to those seen in cells grown in $5 \times$ P.C. media.

Injection of GH increases nuclear IGF-I transcript levels in hypophysectomised rats, indicating that $\mathrm{GH}$ regulates IGF-I expression through transcriptional activation (Gronowski \& Rotwein 1995) and, consonant with this, we have found that the transcription inhibitor, actinomycin-D, blocks GH effects on IGF-I RNA abundance in ovine hepatocytes (A K Stubbs \& D G Hazlerigg, unpublished observations). The present results are therefore consistent with the view that methionine limitation selectively blocks the transcriptional response to $\mathrm{GH}$, leading to reduced IGF-I expression.

Many recent studies highlight effects on the mTOR pathway as a primary response to amino acid supply in mammalian cells. The most firmly established consequences of altered mTOR activity are changes in the phosphorylation state and activity of elements controlling ribosomal activity - in particular p70 S6 kinase and 
eukaryotic initiation factor 4 binding protein-1 (Hara et al. 1998). Since changing activity of these factors has differential consequences for translation of different classes of RNA species - with those encoding regulatory proteins often being particularly sensitive (Jefferies et al. 1997), altered mTOR activity potentially has multiple downstream consequences beyond affecting overall cellular protein synthesis rates. This is highlighted by the recent demonstration that rapamycin treatment affects the phosphorylation and activity of the transcription factors STAT3 and C/EBPa (Hemati et al. 1997, Yokogami et al. 2000).

We therefore examined the effects of general and selective amino acid limitation on p70 S6 kinase phosphorylation in ovine hepatocytes. As predicted, p70 S6 kinase phosphorylation was sensitive to amino acid availability in ovine hepatocytes, and selective limitation of methionine caused a partial reduction in phosphorylation of this enzyme. Although these data are consistent with the idea that the mTOR pathway may contribute to the overall response to methionine limitation, two observations argue that it is not involved in the selective effects on GH-stimulated IGF-I expression. First, limitation of the branched chain amino acids - which modulate insulin sensitivity in muscle (Garlick \& Grant 1988), had a similar effect on p70 phosphorylation, but had no effect on IGF-I expression. Secondly, the pharmacological inhibitor of mTOR, rapamycin, had no measurable effect on $\mathrm{GH}-$ stimulated IGF-I RNA expression, despite causing the predicted sustained inactivation of another mTOR output - p70 S6 kinase phosphorylation. Together, these data suggest that although amino acids regulate mTOR-dependent signalling in ovine hepatocytes, as in other cell types (e.g. Hara et al. 1998, Patti et al. 1998, Wang et al. 1998, Iiboshi et al. 1999, Shigemitsu et al. 1999), this effect is not sufficient to account for the blockade of GH-induced IGF-I RNA expression seen in methionine-limited cells.

Interestingly, studies of two other amino acid sensitive genes, asparagine synthetase and $\mathrm{CHOP}$ (C/EBPhomologous protein), also suggest that a specific, but as yet unidentified, mechanism exists allowing certain genes to be particularly sensitive to methioinine supply (Fafournoux et al. 2000). The physiological significance of this remains unclear, but it is worth noting that, for ruminants, methionine has been highlighted as the first amino acid to become limiting in some forage and sileage-based diets (Richardson \& Hatfield 1978). This provides a possible rationale for the selective sensitivity of the GH/IGF-I system to methionine reported here, since this phenomenon ensures that the drive to grow is modulated not by general amino acid availability, but by the amino acid least available in the nutrient supply. Studies in rats and pigs indicate that IGF-I expression is sensitive to lysine and tryptophan supply (Harp et al. 1991, Brameld et al. 1999), but neither of these amino acids had any effect on IGF-I release during the present study.
Hence it is possible that the relative importance of specific amino acids in determining hepatic IGF-I expression varies between species in relation to their adaptation to different food sources.

\section{Acknowledgements}

The authors thank the following organisations for support: Biotechnology and Biological Sciences Research Council (N M Wheelhouse, M A Lomax); Scottish Higher Education Funding Council (D G Hazlerigg, M A Lomax).

\section{References}

Brameld JM, Gilmour RS \& Buttery PJ 1999 Glucose and amino acids interact with hormones to control expression of insulin-like growth factor-I and growth hormone receptor mRNA in cultured pig hepatocytes. Journal of Nutrition 129 1298-1306.

Breier BH, Gluckman PD \& Bass JJ 1988 Influence of nutritional status and oestradiol-17 $\beta$ on plasma growth hormone, insulin-like growth factors-I and -II and the response to exogenous growth hormone in young steers. Journal of Endocrinology 118 243-250.

Campbell L, Wang X \& Proud CG 1999 Nutrients differentially regulate multiple translation factors and their control by insulin. Biochemical Journal 344 433-441.

Fafournoux P, Bruhat A \& Jousse C 2000 Amino acid regulation of gene expression. Biochemical Journal 351 1-12.

Garlick PJ \& Grant I 1988 Amino-acid infusion increases the sensitivity of muscle protein-synthesis in vivo to insulin - effect of branched-chain amino-acids. Biochemical Journal 254 579-584.

Gluckman PD, Breier BH \& Davis SR 1987 Physiology of the somatotropic axis with particular reference to the ruminant. Journal of Dairy Science 70 442-466.

Gronowski AM \& Rotwein P 1995 Rapid changes in gene expression after in vivo growth hormone treatment. Endocrinology 136 4741-4748.

Hara K, Yonezawa K, Weng Q-P, Kozlowski MT, Belham C \& Avruch J 1998 Amino acid sufficiency and mTOR regulate p70 S6 kinase and eIF-4E BP1 through a common effector mechanism. Journal of Biological Chemistry 273 14484-14494.

Harp JB, Golstein S \& Philips LS 1991 Nutrition and somatomedin XXIII. Molecular regulation of IGF-I by amino acid availability in cultured hepatocytes. Diabetes 40 95-101.

Hemati N, Ross SE, Erickson RL, Groblewski GE \& MacDougald OA 1997 Signaling pathways through which insulin regulates CCAAT/enhancer binding protein $\alpha(\mathrm{C} / \mathrm{EBP} \alpha)$ phosphorylation and gene expression in 3T3-L1 adipocytes. Journal of Biological Chemistry 272 25913-25919.

Iiboshi Y, Papst PJ, Kawasome H, Hosoi H, Abraham RT, Houghton PJ \& Terada N 1999 Amino acid dependent control of $\mathrm{p} 70^{\mathrm{s} 6 \mathrm{k}}$. Journal of Biological Chemistry 274 1092-1099.

Jefferies HBJ, Fumagalli S, Dennis PB, Reinhard C, Pearson RB \& Thomas G 1997 Rapamycin suppresses 5'TOP mRNA translation through inhibition of p70 S6K. EMBO Journal 16 3693-3704.

Ketelslegers J-M, Maiter D, Maes M, Underwood LE \& Thissen J-P 1995 Nutritional regulation of insulin-like growth factor-I. Metabolism 44 50-57.

Kriel GV, Bryant MJ \& Lomax MA 1982 Effect of dietary protein intake and intravenous glucose infusion on plasma concentration of insulin-like growth factor-I in lambs. Journal of Endocrinology 132 195-199.

Lobley GE, Connell A, Lomax MA, Brown DS, Milne E, Calder AG \& Farningham DAH 1995 Hepatic detoxification of ammonia in the ovine liver; possible consequences for amino acid catabolism. British Journal of Nutrition 73 667-685. 
Patti M-E, Brambilla E, Luzi L \& Kahn CR 1998 Bi-directional modulation of insulin action by amino acids. Journal of Clinical Investigation 101 1519-1529.

Pell JM, Saunders JC \& Gilmour RS 1993 Differential regulation of transcription initiation from insulin-like growth factor-I (IGF-I) leader exons and of tissue IGF-I expression in response to changed growth hormone and nutritional status in sheep. Endocrinology 132 1797-1807.

Proud CG \& Denton RM 1997 Molecular mechanisms for the control of translation by insulin. Biochemical Journal 328 329-341.

Richardson CR \& Hatfield EE 1978 The limiting amino acids in growing cattle. Journal of Animal Science 46 740-745.

Schwander JC, Hauri C, Zapf J \& Froesch ER 1983 Synthesis and secretion of insulin-like growth factor and its binding protein by the perfused rat liver: dependence on growth hormone status. Endocrinology 113 297-305.

Shigemitsu K, Tsujishita Y, Hara K, Nanahoshi M, Avruch J \& Yonezawa K 1999 Regulation of translational effectors by amino acid and mammalian target of rapamycin effector pathways. Journal of Biological Chemistry 272 1058-1065.

Silha JV, Gui YT, Modric T, Suwanichkul A, Durham SK, Powell DR \& Murphy LJ 2001 Overexpression of the acid-labile subunit of the IGF ternary complex in transgenic mice. Endocrinology 142 4305-4313.

Sjögren K, Liu J-L, Blad K, Skrtic S, Vidal O, Wallenius V, LeRoith D, Törnell J, Isaksson OGP, Jansson J-O \& Ohlsson C 1999 Liver-derived insulin-like growth factor I (IGF-I) is the principal source of IGF-I in the blood but it is not required for postnatal body growth in mice. PNAS 96 7088-7092.

Thissen J-P, Pucilowski JB \& Underwood LE 1994 Differential regulation of insulin-like growth factor I (IGF-I) and IGF binding protein-1 messenger ribonucleic acids by amino acid availability and growth hormone in rat hepatocyte primary culture. Endocrinology 134 1570-1576.

Van de Haar MJ, Moats-Staats BM, Davenport ML, Walker JL, Ketelslegers J-M, Sharma BK \& Underwood LE 1991 Reduced serum concentrations of insulin-like growth factor-I (IGF-I) in protein-restricted growing rats are accompanied by reduced IGF-I mRNA levels in liver and skeletal muscle. Journal of Endocrinology 130 305-312.

Wang X, Campbell LE, Miller CM \& Proud CG 1998 Amino acid availability regulates p70 S6 kinase and multiple translation factors. Biochemical Journal 334 261-267.

Wheelhouse NM, Stubbs AK, Lomax MA, MacRae JC \& Hazlerigg DG 1999 Growth hormone and amino acid supply interact synergistically to control insulin-like growth factor-I production and gene expression in cultured ovine hepatocytes. Journal of Endocrinology 163 353-361.

Wyn PC, Stuart MC, Wallace ALC, Kirby AC \& Annison EF 1991 Influence of nutritional status on growth hormone-dependent circulating somatomedin-C in mature sheep. Journal of Endocrinology $130313-320$.

Yakar S, Liu J-L, Stannard B, Butler A, Accili D, Sauer B \& LeRoith D 1999 Normal growth and development in the absence of hepatic insulin-like growth factor-I. PNAS 96 7324-7329.

Yokogami K, Wakisaka S, Avruch J \& Reeves SA 2000 Serine phosphorylation and maximal activation of STAT3 during CNTF signaling is mediated by the rapamycin target mTOR. Current Biology 10 47-50.

Received in final form 25 April 2002

Accepted 26 April 2002 